\title{
Ethanol mediated enhancement in bacterial transformation
}

\author{
Arun Dev Sharma* \\ Department of Biotechnology \\ Lyallpur Khalsa College \\ Jalandhar, Punjab, India \\ Tel: 910181224146668 \\ Fax: 9101812241465 \\ E-mail: arundevsharma@rediffmail.com \\ Jaspreet Singh \\ Department of Biotechnology \\ Lyallpur Khalsa College \\ Jalandhar, Punjab, India \\ Prabhjot Kaur Gill \\ Lovely Institute of Higher Studies \\ Phagwara, Near Chearu Bridge \\ Dist- Kapurthala, Punjab, India
}

Financial support: Management Lyallpur Khalsa College.

Keywords: bacteria, ethanol, transformation.

Abbreviations: LB: Luria Broth

In molecular biology, transformation using $E$. coli as a host plays a key role in synthesizing gene libraries. The present study demonstrated a new ethanol-based method for transformation of plasmid DNA to $E$. coli. Ethanol at $10 \%$ concentration (v/v) showed best results. Further, as compared with traditional $\mathrm{CaCl}_{2}$ method, the transformation rate, using protocol outlined in this study, was very high, suggesting amenable for further applications.

The technique of DNA transformation of E. coli is of utmost importance in all aspects of molecular genetics especially in constricting random libraries (Sambrook and Russel, 1989). Although some basic methods are commonly used for bacterial DNA transformation (Sambrook and Russel, 1989; Sheng et al. 1995; Thompson et al. 1998; Van Der Rest et al. 1999; Ensser, 2006; Neumann et al. 1996), however the ability to consistently produce highly transformed $E$. coli cells still remains elusive (Hengen, 1996). Procedures based on simple $\mathrm{CaCl}_{2}$ wash method provide a fair number of transformants $(1 \mathrm{x}$ $10^{4}$ to $1 \times 10^{6}$ transformants per $\mu \mathrm{g}$ of DNA) which can just be used to change bacterial hosts or in propagation of plasmid. However, it could amount to substantial loss of recombinants when efficiency is of utmost importance during constructing random libraries (Fiedler and Wirth, 1988). Therefore, a protocol for obtaining high transformation rates needs attention. Even some increasingly commercial suppliers are offering commercial kits and instruments that are claimed to provide the best transformation efficiency, however, all these are cost effective, and time consuming. Therefore, new transformation methods should be publicly available for obtaining high transformation efficiency. Since in our laboratory, we are engaged often in DNA preparations for several purposes such as PCR amplification, sub-cloning, gene cloning and expression studies. Therefore, we found it a prerequisite to develop a rapid and high yielding transformation protocol. The protocol described here is the modification of basic $\mathrm{CaCl}_{2}$ method (Sambrook and Russel, 1989) in coupling with ethanol which is a well known membrane perturbant. The transformation process, being a membrane-bound phenomenon, is most likely to be influenced by the ethanol. The method is simple, reproducible, not requiring ultracentrifugation, and additional steps. Furthermore, the transformation rate is consistently high which could be amenable for further downstream applications.

\section{MATERIALS AND METHODS}

The culture was obtained by inoculating $4 \mu$ l of frozen glycerol stock cultures (E. coli DH5a) into $4 \mathrm{ml}$ of culture media. Culture was grown in Luria Broth (LB) at $37^{\circ} \mathrm{C}$. The culture pellet was obtained by centrifugation at $5000 \mathrm{~g}$ for 5 min at $4^{\circ} \mathrm{C}$. Transformants were identified on selective LB

*Corresponding author 
Table 1. Transformation rates of $E$. coli cells treated with different concentrations of ethanol. Results represent the average of three experiments.

\begin{tabular}{|c|c|}
\hline $\begin{array}{c}\text { Concentration of } \\
\text { ethanol in \% (v/v) }\end{array}$ & $\begin{array}{c}\text { Transformation rate } \\
\text { (No. of transformants per } \boldsymbol{\mu g} \text { of DNA) }\end{array}$ \\
\hline $0.0(\mathrm{c})$ & $1 \times 10^{4}$ \\
\hline 5.0 & $1 \times 10^{7^{*} \mathrm{a}}$ \\
\hline 7.5 & $1 \times 10^{7^{*} \mathrm{a}}$ \\
\hline 10.0 & $1 \times 10^{10^{*}}$ \\
\hline 12.5 & $1 \times 10^{6^{*}}$ \\
\hline 15.0 & $1 \times 10^{5^{*}}$ \\
\hline
\end{tabular}

*significant difference vs: $\mathrm{c}(0.0 \%)$ at $\mathrm{P} \leq 0.05,{ }^{\mathrm{a}}$ not significantly different $(5.0 \mathrm{vs}: 7.5)$.

agar plates containing $50 \mu \mathrm{g}$ of ampicillin/ml. Plasmid (pUC 19) isolation from the transformants were carried out as per Sambrook and Russel (1989). Data obtained was subjected to ANOVA.

Transformation protocol is as follows:

- Set up a $4 \mathrm{ml}$ of microbial culture and pellet the cells in $2.0 \mathrm{ml}$ tubes by centrifugation at $5000 \mathrm{xg}$ for $5 \mathrm{~min}$ at $4^{\circ} \mathrm{C}$. (The cells were grown to log phase (up to $\left.(\mathrm{OD})_{600}=0.45\right)$ ).

- Resuspend the cell pellet in $1 \mathrm{ml}$ of ice-cold $0.1 \mathrm{M} \mathrm{CaCl}_{2}$ solution and incubate for $40 \mathrm{~min}$ on ice.

- Centrifuge at $5000 \mathrm{~g}$ for $5 \mathrm{~min}$ at $4^{\circ} \mathrm{C}$ and discard the supernatant.

- Again resuspend the pellet in $1 \mathrm{ml}$ of $0.1 \mathrm{M} \mathrm{CaCl}_{2}$ solution.

- Take $200 \mu \mathrm{l}$ of above competent cell suspension into the two different $2.0 \mathrm{ml}$ tubes and add DNA (50 $\mathrm{ng}$ in a volume of $10 \mu \mathrm{l})$.

- To the above tubes add absolute ethanol at the rate of 5.0, 10 , and $15(\%, v / v)$. Mix gently and incubate on ice for 30 min.

- After incubation, transfer the tubes into a water bath being set at $42^{\circ} \mathrm{C}$ and give heat shock for $2 \mathrm{~min}$.

- After heat shock, immediately transfer the tubes to an ice bath.

- Add $800 \mu \mathrm{l}$ of LB broth and incubate the cells at $37^{\circ} \mathrm{C}$ with mild shaking for $45 \mathrm{~min}$ for the expression of antibiotic resistance maker ( $\beta$-lactamase) encoded by the plasmid.

- Now spread $100 \mu 1$ of above suspension on LB plates having ampicillin. Incubate the plates overnight at $37^{\circ} \mathrm{C}$ and calculate the transformation rate.

\section{RESULTS AND DISCUSSION}

The presence of cell wall can hamper transformation procedures and reactions of molecular cloning. Rapid and efficient DNA transformation is often hampered by the presence of microbial cell wall and associated interfering substances (Hengen, 1996). Usually, in practice, the problems linked to presence of cell wall lipopolysaccharides (LPS), which are also supposed to be the major target site for DNA adsorption to the competent cells. Using the protocol outlined in this study, we successfully transformed DNA to $E$. coli with high transformation rates. The key step in our protocol was treatment of competent cells with different concentrations of ethanol, which is being a well-known membrane perturbant. The transformation rate significantly $(\mathrm{P} \leq 0.05)$ increased with increase of ethanol concentration from $5 \%$ to $10 \%$ (Table 1), however decreased at $15 \%$ concentration. This method consistently gave very high transformation efficiency as compared with the basic $\mathrm{CaCl}_{2}$-wash method (Table 1), indicating that transformants are amenable for further downstream applications. Breaking the cell competency barrier could eliminate the need for expensive equipment and special cuvettes sold by the suppliers. The plasmid isolated using this protocol, as seen on agarose gel after electrophoresis and stained with ethidium bromide, consisted of intact plasmid DNA (Figure 1). We repeatedly obtained $\mathrm{A}_{260 / 240}$ ratio greater than 1 , and the $\mathrm{A}_{260 / 280}$ ratio were always between 1.82-1.91, indicating the absence of contaminants.

In summary, our results demonstrated that the newly described method represents a rapid, simple and reproducible method for transformation of DNA to E. coli. We wish to emphasize that ethanol-mediated 


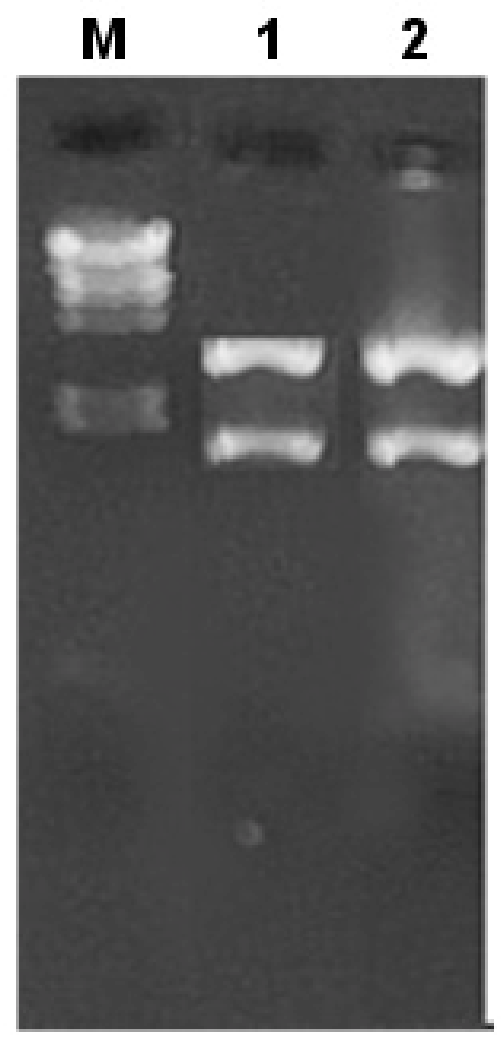

Ethanol mediated enhancement in bacterial transformation

NEUMANN, Eimov; KAKORIN, Suado; TSONEVA, Inika; NIKOLOVA, Bala and TOMOV, Tikkora. Calciummediated DNA adsorption to yeast cells and kinetics of cell transformation by electroporation. Biophysical Journal, August 1996, vol. 71, no. 2, p. 868-877

THOMPSON, Jing R.; REGISTER, Eiva; CUROTTO, Jura; KURTZ, Millo and KELLY, Rano. An improved protocol for the preparation of yeast cells for transformation by electroporation. Yeast, April 1998, vol. 14, no. 6, p. 565571.

SAMBROOK, Joseph and RUSSEL, David W. Molecular cloning: A laboratory manual. $3^{\text {nd }}$ ed. Cold Spring Harbor Laboratory Press, 1989. 213 p. ISBN 0-87-969577-3.

SHENG, Yu-Ling; MANCINO, Valeria and BIRREN, Bruce. Transformation of Escherichia coli with large DNA molecules by electroporation. Nucleic Acids Research, June 1995, vol. 23, no. 11, p. 1990-1996.

VAN DER REST, M.E.; LANGE, C. and MOLENAAR, D. A heat shock following electroporation induces highly efficient transformation of Corynebacterium glutamicum with xenogeneic plasmid DNA. Applied Microbiology and Biotechnology, October 1999, vol. 52, no. 4, p. 541-545.

Figure 1. Agarose gel electrophoreses of plasmid isolated from the transformed $E$. coli cells. M: $\lambda$-Hind-III marker (23-2.0 kb).

Lane 1: plasmid DNA from transformed colony.

Lane 2: commercial plasmid DNA (control).

transformation is a powerful tool for making gene libraries. The protocol has been routinely used in our lab for transformation of DNA.

\section{ACKNOWLEDGMENTS}

A.D. Sharma is thankful to management committee Lyallpur Khalsa College for providing financial assistance for this work.

\section{REFERENCES}

ENSSER, Armin. Transformation by herpesviruses: focus on T cells. Future Virology, January 2006, vol. 1, no. 1, p. 109-121.

FIEDLER, Stefan and WIRTH, Reinhard. Transformation of bacteria with plasmid DNA by electroporation. Analytical Biochemistry, April 1988, vol. 170, no. 1, p. 3844.

HENGEN, Paul N. Methods and reagents: Preparing ultracompetent Escherichia coli. Trends in Biochemical Sciences, February 1996, vol. 21, no. 2, p. 75-76. 